\title{
The Role of Collateral and Personal Guarantees in Relationship Lending: Evidence from Japan's SME Loan Market ${ }^{*}$
}

\author{
Arito $\mathrm{Ono}^{\dagger}$ \\ Mizuho Research Institute Ltd.
}

Iichiro Uesugi ${ }^{\text {I }}$

Hitotsubashi University

This draft: March 2008

First draft: August 2006

\footnotetext{
* The views expressed in this paper are ours and do not necessarily reflect those of the Mizuho Research Institute or any other of the institutions that we are affiliated with. We would like to thank Hans Degryse, Tetsuro Furuta, Akiyoshi Horiuchi, Colin McKenzie, Shinji Mizukami, Hideaki Murase, Zeno Rotondi, Yutaka Soejima, Kotaro Tsuru, and Noboru Yamada, as well as seminar participants at Chuo University, Hitotsubashi University, the Japanese Economic Association, the Japan Society of Monetary Economics, Keio University, the Research Institute of Capital Formation of the Development Bank of Japan, the Shinkin Central Bank Research Institute, the Research Institute of Economy, Trade, and Industry (RIETI) Policy Symposium, the University of Ancona, Warwick Business School, and especially the members of the Corporate Finance Study Group at RIETI for many helpful comments. Any remaining errors are our responsibility.

†Email: arito.ono@mizuho-ri.co.jp

^Email: iuesugi@ier.hit-u.ac.jp
} 


\begin{abstract}
This paper investigates the determinants of the use of collateral and personal guarantees in Japan's SME loan market. We find that firms' riskiness does not have a significant effect on the likelihood that collateral is used. We find, however, that main banks whose claims are collateralized monitor borrowers more intensively, and that borrowers who have a long-term relationship with their main banks are more likely to pledge collateral. These findings are consistent with the theory that the use of collateral is effective in raising the bank's seniority and enhances its screening and monitoring. This incentive effect for the bank becomes tenuous for personal guarantees.
\end{abstract}

JEL classification number: D82, G21, G30

Keywords: collateral, personal guarantees, relationship lending, SME 


\section{Introduction}

A key issue of interest in the recent literature on financial intermediation has been the role of relationship lending. Relationship lending is particularly common in the case of small business lending, because small businesses typically rely on bank loans for a substantial part of their financing needs but also tend to be informationally opaque. An important issue in this context is the use of collateral, which is a common feature of loan contracts between small firms and banks around the world, and a number of theoretical and empirical studies have examined why it is so widespread and how it relates to the incentives for borrowers and lenders and the borrower-lender relationship. For instance, it has been argued that in the presence of information asymmetries between creditors and borrowers, collateral may mitigate the problem of adverse selection (Bester, 1985; 1987) and/or the problem of moral hazard (Bester, 1994; Boot, Thakor, and Udell, 1991). Collateral also affects the incentives of creditors, who will use it either as a substitute for (Manove, Padilla, and Pagano, 2001) or complement to (Rajan and Winton, 1995; Boot 2000; Longhofer and Santos, 2000) screening and monitoring efforts. Another aspect of collateral that studies have concentrated on is that its presence may depend on the length and intimacy of the relationship between creditors and borrowers (Boot, 2000; Boot and Thakor, 1994; Sharpe, 1990). Existing empirical research has yet to reach decisive conclusions about the nature of these relationships.

This paper seeks to contribute to the existing literature on collateral using a unique firm-level data set of the small and medium sized enterprise (SME) loan market in Japan. Explicitly differentiating physical collateral (such as real estate) and personal guarantees by business representatives, we investigate how the use of collateral and personal guarantees affects the incentives of borrowers, lenders, and the relationship between them. More specifically, we examine the following three issues. First, we examine whether riskier borrowers are more likely to be required to provide collateral or personal guarantees. Second, we investigate how collateral and 
personal guarantees affect banks' monitoring of borrowers. Third, we examine the correlation between the use of collateral and personal guarantees on the one hand and the closeness of borrower-lender relationships on the other.

The data set we employ is based mainly on the "Survey of the Financial Environment" (SFE) conducted by the Small and Medium Enterprise Agency of Japan in October 2002. In order to focus on firms that mostly depend on bank loans for their financing, we limit the sample to firms satisfying the legal definition of an SME in Japan. We then combine the SFE data for each SME with information on their main bank obtained from the bank's financial statements in order to control for lender characteristics as well. Furthermore, to control for the effect of government credit guarantees on collateral and personal guarantees, in the main analysis of this paper we exclude from the sample all firms that enjoyed any form of government credit guarantee. ${ }^{1}$ As a result of this screening process, we end up with a sample of 1,702 firms.

Our main findings can be summarized as follows. We find that firms' riskiness does not have a significant effect on the likelihood that collateral is used. Thus, we cannot find firm evidence that the use of collateral mitigates moral hazard. We find, however, that banks whose claims are collateralized monitor borrowers more intensively, and that borrowers who have a long-term relationship with their main bank are more likely to pledge collateral. These findings suggest that collateral is complementary to relationship lending. In contrast, the complementarity between relationship lending and personal guarantees is weaker.

As far as we know, this is the first empirical study that systematically examines the role of collateral and personal guarantees in Japan's SME loan market. The two main contributions of the paper are as follows. First, given that Japan is generally considered to have a relationship-based

\footnotetext{
${ }^{1}$ How we control for the effect of government credit guarantees is explained in detail later. To check the robustness of our main analysis, in Section 4.3 we also include firms some of whose loans are covered by government credit guarantees (firms all of whose loans are fully covered are still excluded). The sample size in this case is 3,945 firms.
} 
financial system in which the relationship-lender, the main bank, plays a central role in corporate financing (Rajan and Zingales, 2003), the study helps to improve our understanding of the role of collateral in relationship lending and complements existing studies that focus on the United States and Europe. Second, and more importantly, by distinguishing collateral and personal guarantees, the study detects an important role of collateral in relationship lending that has not been remarked on much before. As we argue below, although a typical SME in Japan has a long-term relationship with its main bank, it actually engages in transactions with several banks, which is not common in other countries. A possible corollary of this is that because of the informational free-rider problem it creates, this practice may reduce the main bank’s incentive to screen and monitor borrowers. Since collateral defines the order of seniority among creditors, using collateral may mitigate the free-rider problem and enhance the main bank’s screening and monitoring. This incentive effect for the main bank becomes tenuous for personal guarantees, because personal guarantees do not define the seniority among creditors. Thus, our work provides empirical evidence on how collateral affects relationship lenders' incentives, and complements previous studies that focus on the problem of borrower incentives (moral hazard and adverse selection).

The remainder of the paper is organized as follows. Section 2 develops our empirical hypotheses which are based on previous theoretical models and empirical research. Section 3 describes the data and variables that are used in the paper, and explains our empirical model. Section 4 presents the results of our empirical analysis, and Section 5 concludes.

\section{Empirical hypotheses}

\subsection{Borrower riskiness}

Much of the empirical literature in this field examines theoretical predictions of asymmetric information models on the relationship between risk and collateral. If the bank cannot discern 
borrowers' riskiness (hidden information), then collateral may serve as a screening device to distinguish between borrowers and to mitigate the adverse selection problem (Bester, 1985). This follows from the observation that a lower-risk borrower has a greater incentive to pledge collateral than a risky borrower, because of his lower probability of failure and loss of collateral. Hence, the lower-risk borrower will choose the contract with collateral.

On the other hand, if the lender can observe the ex-ante risk, but there are information asymmetries with regard to actions taken by the borrower after the loan is extended, collateral potentially provides an incentive to mitigate moral hazard. Thus, opposite to models focusing on hidden information, those concentrating on hidden action suggest that it is observably riskier borrowers that will pledge collateral, because collateral induces more effort by the borrower (Boot, Thakor, and Udell, 1991), or reduces the incentives of strategic default (Bester, 1994).

Because our data base only contains measures of firms' observed riskiness (namely, credit scores), we couch our first empirical hypothesis as follows:

Hypothesis 1 (H1): The use of collateral is higher among observably higher-risk (low credit score) borrowers if the lender requires collateral in order to mitigate the extent of moral hazard. Alternatively, if borrowers pledge collateral as a signal of their unobserved high credit quality, then there is negative or no relationship between the use of collateral and the credit score.

Consistent with the theory of moral hazard, most existing empirical studies, including Berger and Udell (1990; 1995), have found a positive relationship between collateral and borrowers' ex-ante risk. Jiménez, Salas and Saurina (2006) directly test the adverse selection and moral hazard hypotheses by separating ex-ante and ex-post measures of borrower riskiness, namely defaults prior to and after the loan origination. Their results suggest that although observed riskiness increases the 
likelihood that collateral is used, there is also a negative association between collateral and default after the loan has been granted, which is consistent with the adverse selection argument.

It should be noted that theories of collateral as a solution to moral hazard and/or adverse selection problems assume collateral is external to the firm. ${ }^{2}$ Unfortunately, our measure of the incidence of collateral does not distinguish between firm (inside) collateral and personal (outside) collateral. Hence, throughout our analysis, we will assume that collateral is mostly inside, but allow for the fact that there may also be some outside collateral. As for personal guarantees, they clearly represent outside collateral.

\subsection{Screening and monitoring by the lender}

Recent research on collateral also discusses how collateral affects lenders' incentives with regard to information production, that is, the screening of borrowers' quality and the monitoring of their performance. These theories of the effect of collateral on lenders' incentives apply to both inside and outside collateral. Manove, Padilla, and Pagano (2001), for instance, argue that, from banks' point of view, collateral can be considered as a substitute for the evaluation of the actual risk of a borrower. Thus, banks that are highly protected by collateral may perform less screening of the projects they finance than is socially optimal.

However, several theoretical studies argue that collateral may complement lenders’ screening and monitoring activities. In the presence of other claimants, lenders' incentive to monitor borrowers is reduced due to the informational free-rider problem. In order to enhance lenders' incentive to monitor, loan contracts must be structured in a way that makes lenders' payoff sensitive

\footnotetext{
${ }^{2}$ Possible different roles between outside and inside collateral are empirically explored by Brick and Palia (2007) and Pozzolo (2004). Brick and Palia (2007) find that riskier borrowers are more likely to pledge inside (firm) collateral, but that there is no statistically significant relationship between outside (personal) collateral and borrower risk. In contrast, Pozzolo (2004) finds that physical collateral, which can be either inside or outside, is not associated with borrowers' observed risk, but that personal guarantees (outside collateral) are positively associated with risk.
} 
to borrowers' financial health. Rajan and Winton (1995) argue that collateral may serve as a contractual device to increase lenders' monitoring incentive, because collateral is likely to be effective only if its value can be monitored. Moreover, the use of collateral as an incentive will be more extensive when the value of such collateral (as in the case of accounts receivable and inventories, for example) depreciates rapidly if business conditions deteriorate, than when the value of collateral is relatively stable (as in the case of, e.g., real estate). ${ }^{3}$ Longhofer and Santos (2000) argue that collateral serves as an incentive for information production by the principal lender in the presence of several creditors, because taking collateral is effective in making its loan senior to other creditors' claims. Thus, the bank that provides collateralized loan is able to reap the benefits of screening and monitoring activities. Note that this argument does not straightforwardly apply to personal guarantees, because, in general, personal guarantees do not define seniority among several creditors. $^{4}$

As we have a proxy variable for the intensity of monitoring by the principal lender, our second hypothesis for the empirical analysis is as follows:

Hypothesis 2 (H2): The use of collateral decreases with the intensity of monitoring by the principal lender if collateral reduces lenders' incentive to exert effort in loan management. Alternatively, if collateral serves as an incentive device to induce monitoring efforts by the principal lender in the presence of other claimants, then we expect a positive relationship between the use of collateral and monitoring intensity.

\footnotetext{
${ }^{3}$ Another related benefit of using inventories and accounts receivable as collateral is that they may reveal valuable information about the business (Boot, 2000). This provides further illustration why there are likely to be complementarities between collateral and lenders' monitoring effort.

${ }^{4}$ In contrast, in cases where several creditors take a specific asset as collateral at the same time, it is usually defined who will take the first lien, who will take the second, and so forth.
} 
To our knowledge, there are only two existing studies that empirically assess whether the use of collateral and personal guarantees substitute for or complement screening and monitoring by the lender. Examining Spanish loan data, Jiménez, Salas and Saurina (2006) found that banks with a lower level of expertise (smaller banks and savings banks) in small business lending use collateral more intensively. This is consistent with the theory that collateral is used as a substitute for the evaluation of credit risk. On the other hand, Voordeckers and Steijvers (2006), using Belgian loan data, found that the screening effort by the lender, as approximated by the number of days needed by a bank to judge the credit request, does not significantly affect the probability of collateral being pledged.

The present study complements these works investigating the relationship between collateral and screening by focusing on the relationship between collateral and monitoring using Japanese firm data. Our proxy variable for monitoring intensity is the frequency of document submissions to the main bank.

\subsection{Relationship between the borrower and the lender}

The existing literature on relationship lending provides conflicting predictions on how the strength of the relationship between borrower and lender affects the likelihood of collateral being

pledged. By establishing a solid relationship with the borrower, the lender learns about the hidden attributes and actions of the borrower, thus reducing information asymmetries. Hence, the terms of loan contracts may become more favorable to the borrower if the firm has transactions with a specific relationship lender over a long period of time and thus establishes trust, resulting in a lower likelihood of collateral being pledged (Boot and Thakor, 1994). However, a solid relationship may become detrimental to the borrower if the bank exerts its information monopoly by charging higher interest rates or requiring more collateral (Sharpe, 1990). If such a hold-up problem is indeed 
common, then there is likely to be a positive correlation between the strength of a relationship and the use of collateral. It should be noted that these theories assume that the collateral is outside collateral.

In addition, collateral can also be used as an incentive device in mitigating the soft-budget constraint problem in relationship lending (Boot, 2000). For example, consider the case where a borrower in difficulty asks the bank for more credit and reduced interest obligations in order to avoid default. Although a transaction-based lender would not lend to such a borrower, a relationship lender that has already made loans might accept the borrower's request in the hope of recovering a previous loan. However, once the borrower realizes he can renegotiate the loan contract relatively easily, he has an incentive to misbehave ex ante (the soft budget problem). In such cases, collateral will increase the ex-post bargaining power of the lender and hence reduce the extent of the soft-budget constraint problem, because collateral makes the value of the lender's claim less sensitive to the borrower's total net worth. These theoretical considerations apply to inside collateral as well as outside collateral and lead to the following hypothesis:

Hypothesis 3 (H3): Borrowers that establish a solid relationship with their principal lender are less likely to use collateral if the relationship reduces information asymmetries and enhances mutual trust between the borrower and the lender. Alternatively, borrowers with a strong relationship with their principal lender are more likely to use collateral if the effects of the hold-up problem or the mitigation of the soft-budget constraint problem dominate.

There are a vast number of empirical studies that have investigated how the relationship between a borrower and a lender may affect loan contract terms such as interest rates and collateral requirements in small business lending. The variables used to proxy the relationship vary in the 
literature and include, for example, the duration of the lender-borrower relationship, the number of financial products the borrower has purchased from the lender (to gauge the scope of the relationship), and the number of banks with which the borrower has transactions. Research examining this issue from an empirical perspective, just like the theoretical literature, arrives at mixed results that depend on the proxy variable employed.

Berger and Udell (1995), Brick and Palia (2007), Harhoff and Körting (1998), and Jiménez, Salas and Saurina (2006) find a negative relationship between the duration of bank-firm relationships and the probability that collateral will be pledged. Similarly, Harhoff and Körting (1998), assuming that a high concentration of borrowing from one bank represents a strong lender-borrower relationship, find that the incidence of collateralization of credit lines increases as the number of financial institutions the firm is borrowing from rises. In contrast to these studies, Degryse and Van Cayseele (2000) obtain a positive relationship between the scope of lender-borrower relations and the collateral requirement. And Elsas and Krahnen (2000), using survey data from German banks, find that "house banks" have a higher probability of holding loans backed by collateral and personal guarantees than other banks. As proxies for the lender-borrower relationship, we employ the duration, as well as the scope, of the main bank-borrower relationship, the number of banks with which the borrower has transactions, and a dummy variable that indicates whether the borrower has proprietary transactions with its main bank.

\section{Data, variables, and empirical model}

\subsection{Data}

For the empirical analysis, we employ data from the "Survey of the Financial Environment" (SFE) conducted by the Small and Medium Enterprise Agency of Japan in October 2002. The SFE survey is based on a sample drawn from the "Financial Information Database" of Tokyo Shoko 
Research (TSR), a commercial credit research firm, containing information on more than 1.2 million firms. The SFE questionnaire was sent out to a total of 15,000 companies, mainly SMEs, of which 8,466 responded. Because the Financial Information Database contains the balance sheet and income statements of firms, we have a firm-level data set that includes not only responses to the SFE questionnaire but also the financial statements of the surveyed firms. In order to focus on firms that mostly depend on bank loans for their financing, we limit the sample to those firms satisfying the legal definition of SMEs in Japan, that is, firms with 300 or fewer employees or with registered capital outstanding of 300 million yen or less. We then match our firm-level data with the financial variables of firms’ main banks. These main bank variables come from several sources: the financial statements of banks provided by the Japanese Bankers Association and the Shinkin Bank Association and, for data of banks' SME lending, the October 2002 issue of "Shinyo Hoken Geppo (Credit Insurance Monthly)” published by the Japan Finance Corporation for Small and Medium Enterprise (JASME); in addition, we use banks' annual reports in order to supplement the data that are missing in the other sources. Due to the lack of financial statements data for credit cooperatives, government sponsored financial institutions, and non-banks, we dropped those firms from the sample whose main bank is one of these financial institutions.

For our analysis, the effects of government credit guarantees on collateral and personal guarantees need to be controlled for. Until October 2007, the government-sponsored Credit Guarantee Corporations in principle covered 100 percent of the guaranteed loan amount. ${ }^{5}$ Thus, the use of credit guarantees significantly reduces banks' incentives to require collateral or personal guarantees. To circumvent this problem, we exclude from the sample all SMEs that enjoyed any form of government credit guarantees. As a result, we have 1,702 firms for the main statistical

\footnotetext{
${ }^{5}$ From October 2007, the ratio of credit covered by the credit guarantee corporation was reduced to 80 percent of the guaranteed loan amount.
} 
analysis. The overwhelming majority of sample firms are non-listed firms. ${ }^{6}$

The advantages of our data set are threefold. First, the SFE asks whether the borrowing firm has pledged collateral and/or personal guarantees to the "main bank (relationship lender)." To be precise, the SFE defines collateral as physical assets or securities that the creditor can sell in the event that the borrower defaults. In many cases, the assets pledged as collateral are in the form of real estate. On the other hand, a personal guarantee refers to a contractual obligation of the business representative or other third parties, such as the relatives of the representative or other directors of the borrowing firm, to repay loans in the event of a default. Second, in addition to collateral and personal guarantees, the SFE asks a variety of detailed questions regarding the financial transactions between a borrower and its main bank such as the number of years that the borrower and its main bank have been conducting transactions, the list of financial services that the borrower has purchased from the main bank, and the frequency of document submissions by the borrower to the main bank. These variables enable us to closely investigate how collateral/personal guarantees are related to the monitoring activities of the main bank and to the closeness of the borrower-lender relationship. Third, by matching the SFE data with SMEs' and banks' financial statements data, we are able to control for borrowing firm and main bank characteristics in examining the determinants of collateral/personal guarantees. In addition, the Financial Information Database published by TSR also contains the credit score of sample firms that, as well as financial statement variables, takes non-financial statement items such as the firm's reputation into account, and we use the credit score as a proxy for firms’ riskiness.

Although our data set contains the most detailed data available on financing in Japan, several caveats need to be mentioned. First, even though all the firms in the sample correspond to the legal definition of SMEs, their average size is larger than that of the total population of SMEs in Japan.

\footnotetext{
${ }^{6}$ Only 58 of the 1,702 companies in our sample are listed.
} 
There are about 1.5 million company SMEs and 2.8 million proprietorship SMEs in Japan. ${ }^{7}$ Our analysis is limited to companies and does not include proprietorships due to the lack of financial statement data for proprietorships. Even among companies, only relatively sizeable ones have the resources to regularly produce financial statements and report them to the TSR. We will discuss this issue further below. The second caveat is that questions in the SFE are about transactions between a firm and its main bank, but not about individual loan contracts. Therefore, if a firm has multiple loan contracts with its main bank with different contract terms on the provision of collateral and personal guarantees, the use rates of collateral and personal guarantees are upward biased. The third caveat is that, as is the case in most surveys, the SFE only deals with surviving firms, although it does include firms that have previously defaulted. And fourth, the SFE does not distinguish inside and outside collateral.

To circumvent the possible biases caused by the relatively large size of our sample firms, we implement two robustness checks in the next section. First, we divide the sample into two subsamples based on the number of employees. Second, we include firms using government credit guarantees for some but not all of their loans. Although the Credit Guarantee Corporations secure 100 percent of the guaranteed loan amount, this does not necessarily mean that the main bank bears no credit risk with respect to that firm, since the bank may have extended loans without credit guarantees to the same firm as well. Because the SFE asks firms using credit guarantees whether loans outstanding from the main bank are fully covered by the credit guarantee program, we can identify borrowing firms that partially use credit guarantees for loans from its main bank. Therefore, as long as the main bank bears some credit risk with regard to such firms, it continues to face incentives to screen and monitor borrowers and to build long-term relationships. Incorporating these firms increases our sample size and reduces the average size of sample firms: the sample size grows

\footnotetext{
${ }^{7}$ The figures are from the "Establishment and Enterprise Census in Japan 2004” published by the Ministry of Internal Affairs and Communications.
} 
from 1,702 firms to 3,945 firms, while the average and the median numbers of employees are 108.3 and 61.5 for firms none of whose loans are covered by the credit guarantees and 75.7 and 40.0 for firms some but not all of whose loans are covered by the credit guarantees.

\subsection{Variables}

A list of the variables used in our empirical analysis and their definitions is provided in Table 1, while Table 2 presents summary statistics of these variables for the sample of firms without any credit guarantees. The summary statistics for the sample including firms that enjoy credit guarantees for some (but not all) of their loans are provided in the Appendix.

\section{[Insert Tables 1 and 2]}

The dependent variables, COLL and GUAR, are dummy variables that take a value of 1 if the borrower pledges collateral/personal guarantees to its main bank. The use ratios of collateral and personal guarantees are 71.7 percent and 66.7 percent, respectively. The key explanatory variables for our empirical analysis are organized to correspond to our hypotheses: a variable relating to the riskiness of the borrower, a variable relating to monitoring by the lender, and variables on the relationship between the borrower and the lender.

To examine Hypothesis 1, borrowers' riskiness is proxied by the credit score (SCORE) provided by the TSR. Financial institutions view the TSR's credit score as a common metric of credit risk for SMEs in Japan. In addition, the credit score is likely to be negatively correlated with the default rate. ${ }^{8}$ The score ranges from 0 to 100 points, with a higher credit score implying a lower

\footnotetext{
${ }^{8}$ The TSR does not disclose the ex-post default rate by credit score, but several studies using the credit scores provided by Teikoku Data Bank (TDB), another major credit research firm in Japan, report that the TDB credit score is negatively correlated with the ex-post default rate. See, for instance, Mori et al. (2002). The
} 
credit risk. The score consists of four components: (i) management ability (such as the business experience of the manager) and outstanding assets that can be collateralized (20 points); (ii) the growth potential of sales and profits (25 points); (iii) stability factors such as firm age, the amount of capital outstanding, and the payment and credit history of the firm (45 points); and (iv) reputation and disclosure (10 points). The score is subjective in the sense that each TSR researcher grades the firms for which he is responsible, and researchers are asked to assign a score of 50 points to the "average" firm with which they are working. Table 2 shows that the mean of SCORE is 59.1, suggesting that our sample is skewed toward relatively "good” firms. We expect a negative sign for SCORE if the moral hazard hypothesis applies.

Monitoring by the lender is proxied by the variable DOC_FREQ, which is used to examine Hypothesis 2. The SFE asks respondent firms how often they submit relevant documents such as financial statements and cash flow forecast tables to their main bank so that banks can assess borrowers' credit risk, and we use this information as a proxy for the intensity of monitoring by the main bank. The index variable DOC_FREQ shows the frequency of such submissions, with 1 indicating the highest frequency and 4 the lowest frequency. ${ }^{9}$ The mean of DOC_FREQ is 3.0. We expect a positive sign for DOC_FREQ if collateral leads main banks to reduce their monitoring efforts. Alternatively, if collateral serves as an incentive device to induce efforts by the main bank, then the sign for DOC_FREQ should be negative.

Finally, to investigate Hypothesis 3, we use the following lender-borrower relationship variables; DURATION (in logarithm), which represents the duration of the main bank-borrower

TDB credit score is constructed in a similar way as the TSR credit score.

${ }^{9}$ We investigated the frequency of document submission (DOC_FREQ) by type of bank to examine whether particular types of banks monitor borrowers more intensively, as posited in Jiménez, Salas and Saurina (2006). However, we do not find any relationship between the type of bank and monitoring intensity. This lends support to our empirical strategy of not positing a priori which type of lenders have a relative advantage in evaluating and managing the credit risks involved in small business lending. Several lender characteristics will be taken into account below. 
relationship: SCOPE, which indicates the number of financial products the borrower has purchased from its main bank (the scope of the relationship); and BANKS, which stands for the number of banks with which the borrower has transactions. We also construct a dummy variable, ONE_BANK, which takes a value of 1 if the borrower has proprietary transactions with its main bank. Similar to the definition of a "house bank” in Elsas and Krahnen’s (2000) study on Germany, the definition of a main bank in the SFE is somewhat subjective as each respondent firm is asked to choose its main bank based on its own perceptions. As for SCOPE, the SFE asks firms to list all products, other than loans, which they have purchased from their main bank. ${ }^{10}$ We then tabulate the number of products that each firm has purchased. The means of the variables are 32.6 years for DURATION, 4.2 products for SCOPE, and 4.1 banks for BANKS. In comparison with other countries, the duration of bank-borrower relationships in Japan is extremely long, and the number of banks with which SMEs have transactions is fairly large. ${ }^{11}$ We would expect a negative sign for DURATION and SCOPE, and a positive sign for BANKS if a closer relationship between a borrower and a lender reduces the use of collateral, and vice versa otherwise.

Other than the key variables above, we include variables to control for loan contract terms, borrower characteristics, and lender characteristics. Loan contract terms are GUAR in the collateral equation (and COLL in the personal guarantees equation) and RATE. We use the dependent variable of one equation (say, GUAR) as an explanatory variable in the other equation (the collateral equation in this case). The variable RATE indicates the short-term interest rate on a firm's loan from its main bank as of the end of October 2002, in percentage points. If the borrower has several

\footnotetext{
${ }^{10}$ See Table 1 for the precise construction of this variable.

${ }^{11}$ The average number of years for borrower-lender relationships in previous studies are 11.4 (Berger and Udell, 1995) and 8.5 (Brick and Palia, 2007) for the United States; 12.8 for Germany (Harhoff and Körting, 1998), 7.9 for Belgium (Degryse and Cayseele, 1999) and 3.2 for Spain (Jiménez, Salas and Saurina, 2006). The average number of banks with which small businesses have transactions is 1.2 in the United States (Brick and Palia, 2007), 1.8 in Germany (Harhoff and Körting, 1998), and 4.0 in Spain (Jiménez, Salas and Saurina, 2006).
} 
short-term loans with its main bank, then the loan with the highest interest rate is reported. The mean of RATE is 1.667 percent - quite a low level, which is due to the stagnation of the Japanese economy and ultra-loose monetary policy at that time. These contract terms are potentially endogenous, and we discuss how we deal with the problem of endogenous regressors below.

We also control for borrower and main bank characteristics with which the use of collateral and personal guarantees may be associated. There are four variables to represent borrower characteristics. The variable LOGSALES is the logarithm of annual gross sales of the firm and stands for the size of the firm. ${ }^{12}$ The variable CASH_RATIO (cash holdings/gross sales) represents the liquidity position of the firm. The variable MATURITY is the ratio of short-term to long-term loans of the firm. Because long-term loans such as for equipment and real estate are more likely to be secured by these assets, we expect a negative correlation between MATURITY and the use of collateral. ${ }^{13}$ We also control for the industry the firm belongs to by constructing nine industry dummy variables.

We use three variables for lender (main bank) characteristics: SME_LOANS, BANK_SHARE, and NPL.SME_LOANS is the ratio of SMEs loans to total loans and is intended to capture the main bank's degree of specializing in SME lending. BANK_SHARE is the share of a bank's assets to total banking sector assets and represents the size of the main bank. Finally, NPL is the ratio of nonperforming loans to total loans.

\subsection{Empirical model}

To examine Hypotheses 1, 2, and 3, we estimate the following equation:

\footnotetext{
${ }^{12}$ As alternatives, we also use the logarithm of assets and the logarithm of the number of employees as proxies for firm size. The results obtained are essentially the same as when we use LOGSALES.

${ }^{13}$ Ideally, we would like to control the weighted average maturity of the firm's loans from its main bank. However, as noted above, because the questions in the SFE are not about individual loan contracts, we do not have such data.
} 


$$
\begin{aligned}
& \operatorname{Pr}\left(Y_{i j}=1\right)=f\left(\text { SCORE }_{j}, \text { DOC }_{-} \text {FREQ }_{i j}, \text { RELATION }_{i j},\right. \\
& \text { FIRM } \left._{j}, \text { LENDER }_{i}, \text { TERMS }_{i j}, \text { INSTRUMENTS }_{j}\right)
\end{aligned}
$$

where $Y_{i j}$ is either $C O L L_{i j}$ or $G U A R_{i j}$. $S C O R E_{j}$ is the TSR credit score of firm $j$. DOC_FREQ $Q_{i j}$ is the frequency of document submissions by firm $j$ to its main bank $i . R E L A T I O N_{i j}$ is a vector of variables indicating the bank-firm relationship, and $F I R M_{j}$ and $L E N D E R_{i}$ are vectors of variables indicating firm and lender characteristics. We also control for the contracting terms (TERMS $i j)$ such as the interest rate, $R A T E_{i j}$, and whether the borrower also pledges a guarantee or collateral to its main bank. These variables are potentially endogenous, and we formally examine the exogeneity of these contract terms variables below. In those cases where at least one of the variables turns out to be endogenous, we use instrumental variables. The instrumental variables for interest rates are measures of market power and the age of the borrowing firm (FIRMAGE $)$. We use the Herfindahl Index for SME loans in the prefecture of the firm, denoted as $H H I_{j}$, as our market power measure. Since we cannot obtain figures for each city bank's SME loans outstanding in each prefecture, $H_{H} I_{j}$ is computed based on the share of SME loans outstanding for banks other than city banks, that is, smaller banks including regional banks, second-tier regional banks, Shinkin banks, and Shinkumi banks (credit cooperatives). To compensate for this deficiency of our Herfindahl Indices, we also include the aggregated share of city banks in SME loans in the prefecture of the firm (CITY_SHARE $)_{j}$. These market power variables are taken from the "Regional Finance Map 2002” published in the Kinyu Journal. Two instrumental variables for personal guarantees are employed, $O W N E R \_R E P_{j}$ and $O W N E R \_F A M I L Y_{j}$. $O W N E R \_R E P_{j}$ is a binary variable that takes unity if the surname of the representative of the firm matches that of one of the major shareholders, while OWNER_FAMILY $Y_{j}$ counts the number of major shareholders whose surname is identical to that of the representative. These variables are useful in approximating the risk of commingling of business assets and the personal assets of the owner, which makes the use of personal guarantees more likely. 
The instrumental variable for collateral is the ratio of real estate holdings to total assets $\left(L A N D \_R A T I O_{j}\right)$. Because real estate is the asset most frequently used as collateral in lending to SMEs in Japan, ${ }^{14}$ we believe $L A N D \_R A T I O_{j}$ is an appropriate instrumental variable for collateral. The validity of these instruments will be formally tested in our analysis below.

We begin with the probit estimations for collateral and personal guarantees, assuming that the contract terms are exogenous explanatory variables. For example, regarding the probit estimation for collateral, the interest rates $R A T E_{i j}$ and the binary variable for personal guarantees $G U A R_{i j}$ are assumed to be exogenous. We then implement tests for exogeneity of $R A T E_{i j}$ and $G U A R_{i j}$ (in the case of the collateral equation) applying the methodology of Rivers and Vuong (1988) and Wooldridge (2002, p. 474). The procedure is as follows: (i) We run the OLS regression for possibly endogenous variables, $R A T E_{i j}$ and $G U A R_{i j}$, on all other independent variables (including instrumental variables) and obtain the reduced form residuals. (ii) We then run the probit regression for $C O L L_{i j}$ on all exogenous variables (including possibly endogenous variables and their instrumental variables) and the residuals obtained in the first step. If the t-statistics on these residuals show they are insignificant, then we fail to reject the null that the contract terms are exogenous and thus adopt the probit estimations that treat the contract term variables as exogenous. If one (or both) of the contract term variables turns out to be endogenous, we then check the validity of the instrumental variables by regressing the instrumented variable on the instrumental variables. Finally, we employ Wooldridge’s (2002, pp. 477-478) maximum likelihood estimation (MLE) procedure with the endogenous variable. The idea is to obtain the parameters of the model and their standard errors by maximizing the likelihood function of the following equation:

\footnotetext{
${ }^{14}$ The 2001 SFE provides the composition of collateral by type of assets pledged (multiple answers allowed). Among those respondent firms that pledged collateral to their main bank, 95.9 percent answered that they pledged real estate. Other collateralized assets, in their order of importance following real estate, are deposits (22.8 percent), equity securities (9.2 percent), and commercial bills (6.9 percent).
} 


$$
f\left(Y_{i j}, \text { TERMS }_{i j} \mid \mathbf{z}\right)=f\left(Y_{i j} \mid \text { TERMS }_{i j}, \mathbf{z}\right) f\left(T_{E R M S} \mid \mathbf{z}\right)
$$

where $\mathbf{z}$ is a vector of instrumental variables.

\section{Empirical results}

\subsection{Collateral}

Table 3 reports the benchmark probit estimation in which contract terms are treated as exogenous variables for the sample of firms without government credit guarantees. Note that the coefficients on both contract terms variables, GUAR and RATE, are positive and highly significant, indicating that borrowers who pledge personal guarantees and incur higher short-term interest rates are more likely to have collateralized loans. Regarding our empirical hypotheses, the estimation results in Table 3 show that a firm's riskiness does not have any significant effect on the use of collateral, that a more frequent submission of relevant documents is associated with a greater use of collateral, and that the longer the duration and the wider the scope of the relationship, the more likely it is that the borrower pledges collateral.

[Insert Table 3]

The lower part of Table 3 reports the exogeneity tests for GUAR and RATE. The z-statistics of the residual terms obtained from the first-step estimation for GUAR and RATE indicate that we can reject the null hypothesis that GUAR is exogenous, but that we cannot reject the null that RATE is exogenous. Thus, we proceed to the MLE estimation in which only GUAR is treated as endogenous. To begin with, Table 4 assesses the explanatory power of our instrumental variables for personal guarantees. In cases where the instrumental variables alone or both the instruments and other exogenous variables are incorporated as regressors, we reject the null that coefficients on 
OWNER_REP and OWNER_FAMILY are jointly zero. Thus, we can use these instrumental variables with some confidence.

\section{[Insert Table 4]}

Table 5 reports the MLE estimation for the collateral equation in which GUAR is treated as endogenous. In terms of our empirical hypotheses, the results are qualitatively the same as the benchmark estimation in Table 3 where GUAR is treated as an exogenous variable. The coefficient on SCORE is again insignificant, and thus the moral hazard hypothesis is not supported. ${ }^{15}$ This may be because our collateral variable does not differentiate inside and outside collateral. The coefficient on DOC_FREQ is negative and significant, and thus provides support for the hypothesis that collateral serves as an incentive for monitoring efforts by the main bank. Finally, the coefficients on LOGDURATION and SCOPE are both positive and significant, which is consistent with the hypothesis that a stronger borrower-lender relationship contributes to the use of collateral, presumably because of the hold-up problem or because collateral is used to mitigate the soft-budget constraint problem.

\section{[Insert Table 5]}

Taken together, our empirical results suggest that, in Japan, collateral is complementary to relationship lending. As noted above, unlike in some of the other developed countries, SMEs in Japan tend to have transactions with a fairly large number of banks. Under such circumstances, a

\footnotetext{
${ }^{15}$ If the borrower uses collateral as a signaling device of his unobservable high credit quality, then there may be no relationship between collateral usage and SCORE. Our data reveals, however, that the interest rate at which firms borrow is higher for those pledging collateral than those that do not - a result that is in contradiction with the signaling hypothesis.
} 
main bank's incentive to screen and monitor borrowers and establish relationships may be reduced due to the informational free-rider problem. Collateral works as an incentive for main banks to invest in relationship building, because in Japan it is usually the case that the main bank takes a first lien on collateral so that its claims are senior to those of other lenders.

Turning to the other control variables, the coefficients on LOGSALES and LAND_RATIO are positive and significant, indicating that larger firms and firms where real estate makes up a larger share of their assets are more likely to pledge collateral. The negative coefficient on MATURITY implies that the larger a firm's ratio of short-term to long-term loans, the less likely it is that it will pledge collateral to its main bank. Finally, the negative coefficient on SME_LOANS implies that banks whose loan portfolios are more concentrated on SME lending are less likely to require collateral.

\subsection{Personal guarantees}

Table 6 reports the benchmark probit estimation for personal guarantees and the exogeneity tests for COLL and RATE. Unlike in the collateral equation, we cannot reject the null hypotheses that COLL and RATE are exogenous. Hence, we proceed with our benchmark estimation. Similar to the results of the collateral equation, we find that the coefficients on both contract terms variables, COLL and RATE, are positive and highly significant. That is, the use of personal guarantees is positively associated with collateral usage and higher interest rates. Regarding our three empirical hypotheses, we find no statistically significant relationships: none of the coefficients on SCORE, DOC_FREQ, LOGDURATION, SCOPE, BANKS, and ONE_BANK is significant. However, we do find that $O W N E R \_R E P$ has a statistically significant positive impact, and that LOGSALES has a significant negative impact on the use of personal guarantees. Taken together, these results suggest

that the main bank requires personal guarantees from smaller firms whose business is strongly 
controlled by the business representative. Because there is more of a commingling risk for smaller and more owner-oriented firms, our empirical results can be interpreted as indicating that the main objective of Japanese banks in asking for personal guarantees in lending to SMEs is to limit the extent of the risk of the commingling of representatives' personal wealth and business assets. With respect to main bank characteristics, we find a significant positive coefficient for SME_LOANS and a significant negative coefficient for $N P L$, indicating that banks with a larger SME loans ratio or a smaller non-performing loans ratio are more likely to ask for personal guarantees from their borrowers.

\section{[Insert Table 6]}

Most importantly, we do not find a complementary relationship between personal guarantees on the one hand and monitoring efforts and borrower-lender relationship variables on the other. Thus, the incentive effect for the lender becomes tenuous in the case of personal guarantees, and a likely explanation for this finding is that, unlike collateral, personal guarantees do not define the seniority among creditors.

\subsection{Robustness}

As explained in Section 3, in the baseline analysis we used a sample that excluded firms that relied on the government-sponsored credit guarantee program. As a result, our sample consists of relatively large SMEs, and the estimation may be influenced by the size of the firms we chose. To verify that our main conclusions above are not distorted by the size of sample firms, we perform two exercises. Firstly, we split our sample and see whether we can obtain similar results. We split our sample along the median number of employees, which is 62, and estimate an instrumental variable probit regression for the collateral equation and a simple probit regression for the personal 
guarantees equation (Tables 7(a) and 7(b)). Both in the collateral equation and in the personal guarantees equation, we obtain qualitatively the same results as in the previous sections for smaller firms with 62 or fewer employees. ${ }^{16}$

[Insert Tables 7(a) and 7(b)]

Secondly, we rerun our regressions using the sample containing firms that relied on credit guarantees for some (but not all) of their loans and that includes smaller SMEs. In order to control for the use of credit guarantees, we add the dummy variable GOVGUAR that takes a value of 1 if the firm used credit guarantees for loans from its main bank. The results are reported in Tables 8(a) and 8(b). A number of things are worth noting. First, the coefficient on SCORE in the collateral equation is still insignificant, and the sign and significance of the coefficients on DOC_FREQ, LOGDURATION, and SCOPE are the same as in the analysis in the previous section. These findings confirm our conclusion that collateral is complementary to relationship lending. Second, in the personal guarantees equation, the coefficient on DOC_FREQ is significantly negative, which also suggests that the use of personal guarantees is positively associated with the intensity of monitoring by the main bank. Regarding the relationship variables in the personal guarantees equation, we obtain a significant positive coefficient for SCOPE, which indicates a complementary relationship between the closeness of lender-borrower ties and personal guarantees. Note, however, that we obtain significant negative coefficients for both BANKS and ONE_BANK, implying a non-linear relationship between the number of banks with which a firms conducts transactions and the probability of pledging personal guarantees. Having transactions with a smaller number of

\footnotetext{
${ }^{16}$ In the personal guarantees equation, the coefficient on LOGSALES is no longer significant, but that on $O W N E R \_R E P$ is still significantly positive, so our conclusion that main banks ask for personal guarantees in order to limit the extent of risk of commingling of owners' personal wealth and business assets still seems to hold.
} 
banks increases the probability of pledging personal guarantees. In contrast, a main bank with no rival lender to extend a loan to a borrower has a smaller incentive to require personal guarantees since it has the priority to receive repayments. ${ }^{17}$

[Insert Tables 8(a) and 8(b)]

\section{Concluding Remarks}

This paper investigated the role of collateral and personal guarantees using a unique data set of Japan's SME loan market. We found that firms' riskiness does not have a significant effect on the likelihood that collateral is used. We found, however, that main banks whose claims are collateralized monitor borrowers more intensively, and that borrowers who have a long-term relationship with their main banks are more likely to pledge collateral. Our empirical evidence thus suggests that collateral is complementary to relationship lending. In contrast, personal guarantees only weakly complement relationship lending.

As far as we know, this is the first empirical study to systematically examine the role of collateral and personal guarantees in SME lending in Japan and as such complements previous studies on collateral that focus on the United States and Europe. More importantly, by distinguishing between collateral and personal guarantees, we were able to detect an important role of collateral in relationship lending that has not been much remarked on before. SMEs in Japan, unlike in other developed countries, tend to have transactions with a fairly large number of banks. Under such circumstances, the incentives for main banks to screen and monitor borrowers and establish solid relationships may be reduced due to the informational free-rider problem. Because it

\footnotetext{
${ }^{17}$ Our empirical results indicate that this argument does not apply for collateral, presumably because the main bank faces the threat that another bank provides a collateralized loan in which the rival takes the first lien. In contrast, because personal guarantees do not define the seniority among creditors, it is sufficient for the main bank to ask the borrower to pledge personal guarantees after the rival bank makes a loan.
} 
defines the order of seniority among creditors, collateral provides an incentive for main banks to invest in relationship building and thus results in greater monitoring efforts. This incentive effect for the lender becomes tenuous for personal guarantees, because these do not define seniority among creditors. Our work thus provides empirical evidence on how collateral affects relationship lenders' incentives, and complements previous studies on collateral that focus on incentive problems on the part of borrowers (moral hazard and adverse selection).

A few caveats with regard to our analysis need to be borne in mind. First, the SFE sample is skewed toward large SMEs, which may bias our empirical results. We tried to circumvent this problem by splitting the sample and by using sample firms whose loans are partially guaranteed by the credit guarantee program, but it may still be the case that our results only apply to fairly sizable, well-established SMEs. Second, although we find evidence that the use of collateral is positively associated with the strength of borrower-lender relationships, we do not exactly know whether this is due to the hold-up problem or lenders' incentive to mitigate the soft-budget constraint problem in relationship lending. In order to evaluate the efficiency of the use of collateral in small business lending, it is important to further investigate the motivation of banks in requiring collateral and personal guarantees. It is also necessary to evaluate whether the enhanced bargaining power of the lender, be it due to hold-up of the borrower or mitigation of the soft budget constraint, increases the availability of credit for small businesses. These issues should be addressed in future studies. 


\section{References}

Berger, Allen N. and Gregory F. Udell. (1990). “Collateral, Loan Quality, and Bank Risk.” Journal of Monetary Economics 25, 21-42.

Berger, Allen N. and Gregory F. Udell. (1995). "Relationship Lending and Lines of Credit in Small Firm Finance.” Journal of Business 68, 351-381.

Berger, Allen N. and Gregory F. Udell. (1998). “The Economics of Small Business Finance: The Roles of Private Equity and Debt Markets in the Financial Growth Cycle.” Journal of Banking and Finance 22, 613-673.

Berger, Allen N. and Gregory F. Udell. (2002). "Small Business Credit Availability and Relationship Lending: The Importance of Bank Organisational Structure.” Economic Journal $112,32-53$.

Bester, Helmut. (1985). “Screening vs. Rationing in Credit Markets with Imperfect Information.” American Economic Review 75, 850-855.

Bester, Helmut. (1987). “The Role of Collateral in Credit Markets with Imperfect Information.” European Economic Review 31, 887-899.

Bester, Helmut. (1994). "The Role of Collateral in a Model of Debt Renegotiation.” Journal of Money, Credit, and Banking 26, 72-86.

Boot, Arnoud W. A. (2000). “Relationship Banking: What Do We Know?” Journal of Financial Intermediation 9, 7-25.

Boot, Arnoud W. A and Anjan V. Thakor. (1994). "Moral Hazard and Secured Lending in an Infinitely Repeated Credit Market Game.” International Economic Review 35, 899-920.

Boot, Arnoud W. A., Anjan V. Thakor, and Gregory F. Udell. (1991). "Secured Lending and Default Risk: Equilibrium Analysis, Policy Implications and Empirical Results.” Economic Journal 101, 458-472. 
Brick, Ivan E. and Darius Palia. (2007). "Evidence of Jointness in the Terms of Relationship Lending.” Journal of Financial Intermediation 16, 452-476.

Degryse, Hans and Patrick Van Cayseele. (2000). "Relationship Lending within a Bank-Based System: Evidence from European Small Business Data.” Journal of Financial Intermediation 9, 90-109.

Elsas, Ralf and Jan Pieter Krahnen. (2000). “Collateral, Default Risk, and Relationship Lending: An Empirical Study on Financial Contracting.” CEPR Discussion Paper No.2540.

Harhoff, Dietmar and Timm Körting. (1998). “Lending Relationships in Germany - Empirical Evidence from Survey data.” Journal of Banking and Finance 22, 1317-1353.

Jiménez, Gabriel, Vincente Salas and Jesús Saurina. (2006). “Determinants of Collateral.” Journal of Financial Economics 81, 255-281.

Longhofer, Stanley D. and João A. C. Santos. (2000). “The Importance of Bank Seniority for Relationship Lending.” Journal of Financial Intermediation 9, 57-89.

Manove, Michael, A. Jorge Padilla, and Marco Pagano. (2001). "Collateral versus Project Screening: A Model of Lazy Banks.” RAND Journal of Economics 32, 726-744.

Mori, Masaki, Soichiro Moridaira, Masanobu Ojima, Kohei Kimura, and Katsushige Iwabuchi. (2002). “Kakuzuke Suii Kakuritsu Gyoretsu no Kikankozo Suitei.” [“Estimating the Term Structure of Transition Matrices for Credit Scores.”] mimeo.

Pozzolo, Alberto F. (2004). “The Role of Guarantees in Bank Lending.” EFMA 2004 Basel Meetings Paper, May 2004.

Petersen, Mitchell A., and Raghuram G. Rajan. (1994). “The Benefits of Lending Relationships: Evidence from Small Business Data.” Journal of Finance 49, 3-37.

Rajan, Raghuram and Andrew Winton. (1995). "Covenants and Collateral as Incentives to Monitor.” Journal of Finance 50, 1113-1146. 
Rajan, Raghuram and Luigi Zingales (2003). Saving Capitalism from the Capitalists: Unleashing the Power of Financial Markets to Create Wealth and Spread Opportunity. Crown Business, New York.

Rivers, Douglas and Quan H. Vuong (1988). “Limited Information Estimators and Exogeneity Tests for Simultaneous Probit Models.” Journal of Econometrics 39, 347-366.

Sharpe, Steven A. (1990). “Asymmetric Information, Bank Lending and Implicit Contracts: A Stylized Model of Customer Relationships.” Journal of Finance 45, 1069-1087.

Voordeckers, Wim and Tensie Steijvers. (2006). "Business Collateral and Personal Commitments in SME Lending.” Journal of Banking and Finance 30, 3067-3086.

Wooldridge, Jeffrey M. (2002). Econometric Analysis of Cross Section and Panel Data. The MIT Press, Cambridge, Mass. 
Table 1. Definitions of Variables

\begin{tabular}{|c|c|}
\hline Variable & Definition \\
\hline \multicolumn{2}{|c|}{ Dependent variables } \\
\hline COLL & 1 if the borrower pledges collateral to its main bank, 0 otherwise. \\
\hline GUAR & 1 if the borrower pledges a personal guarantee to its main bank, 0 otherwise. \\
\hline \multicolumn{2}{|c|}{ Riskiness of borrower } \\
\hline SCORE & TSR Credit Score (0-100). \\
\hline \multicolumn{2}{|c|}{ Monitoring by lender } \\
\hline$D O C \_F R E Q$ & $\begin{array}{l}\text { Index variable indicating the frequency of document submissions to the borrower's main bank: } \\
\text { 1: once every 1-2 months, } 2 \text { : quarterly, } 3 \text { : semi-annually, } 4 \text { : annually. }\end{array}$ \\
\hline \multicolumn{2}{|c|}{ Relationship between borrower and lender } \\
\hline LOGDURATION & Log of the duration of the main bank-borrower relationship in years. \\
\hline SCOPE & $\begin{array}{l}\text { Number of financial products the borrower has purchased from its main bank. Firms surveyed in the SFE are } \\
\text { asked to tick all applicable items from the following list: (i) current account, (ii) term deposit, (iii) draft payment } \\
\text { collection, (iv) settlement of notes payable, (v) foreign exchange transactions, (vi) bond underwriting, (vii) } \\
\text { capital increase underwriting, (viii) bank's capital increase underwritten by the borrower, (ix) receipt of } \\
\text { seconded or former bank employees, (x) business with bank affiliates, (xi) participation in meetings with } \\
\text { customers/suppliers organized by bank, (xii) use of services (e.g. financial consultations) provided by bank, } \\
\text { (xiii) introduction of customers. We exclude items (viii) and (ix), which appear irrelevant for our measure of } \\
\text { the lender-borrower relationship. }\end{array}$ \\
\hline BANKS & Number of banks the borrower has transactions with. \\
\hline ONE_BANK & 1 if the borrower has a single bank it conducts transactions with. \\
\hline \multicolumn{2}{|c|}{ Terms of loan contracts } \\
\hline RATE & $\begin{array}{l}\text { Short-term interest rate charged by the main bank. If the borrower has several short-term loans with its main } \\
\text { bank, the loan with the highest rate is reported. }\end{array}$ \\
\hline GOVGUAR & $\begin{array}{l}1 \text { if the borrower uses government sponsored credit guarantees for the loans provided by its main bank, } 0 \\
\text { otherwise. }\end{array}$ \\
\hline \multicolumn{2}{|c|}{ Borrower characteristics } \\
\hline LOGSALES & Log of gross annual sales. \\
\hline CASH_RATIO & Ratio of cash holdings to total sales. \\
\hline MATURITY & $\begin{array}{l}\text { Ratio of short-term to long-term loans, where short-term loans are defined as loans with a maturity of less } \\
\text { than one year. }\end{array}$ \\
\hline IND1-IND9 & $\begin{array}{l}\text { Borrower dummy variable classified by industry: 1: construction, 2: manufacturing, 3: IT and transportation, 4: } \\
\text { wholesale, 5: retail, 6: real estate, 7: restaurants, 8: services, 9: other. }\end{array}$ \\
\hline \multicolumn{2}{|c|}{ Lender characteristics } \\
\hline SME_LOANS & Ratio of SME loans to total loans. \\
\hline BANK_SHARE & Share of a bank's assets to total banking sector assets. \\
\hline$N P L$ & $\begin{array}{l}\text { Ratio of non-performing loans to total loans. Non-performing loans consist of loans to borrowers in legal } \\
\text { bankruptcy, past due loans in arrears by } 3 \text { months or more, and restructured loans. }\end{array}$ \\
\hline \multicolumn{2}{|c|}{ Instrumental variables } \\
\hline FIRMAGE & Age of the borrowing firm. \\
\hline$H H I$ & $\begin{array}{l}\text { Herfindahl Index for SME loans in the prefecture of the firm. The Herfindahl Index is computed based on the } \\
\text { share of SME loans of regional banks, second-tier regional banks, shinkin banks, and shinkumi banks. }\end{array}$ \\
\hline CITY_SHARE & City banks' share of SME loans in the prefecture of the firm. \\
\hline OWNER_REP & 1 if the last name of the representative matches the surname of one of the major shareholders. \\
\hline OWNER_FAMILY & Number of major shareholders whose surname is identical to that of the representative. \\
\hline LAND_RATIO & Ratio of real estate holdings to total assets. \\
\hline
\end{tabular}


Table 2. Summary Statistics

\begin{tabular}{|c|c|c|c|c|c|c|}
\hline 1 & & Mean & Median & $\begin{array}{l}\text { Standard } \\
\text { deviation }\end{array}$ & Min. & Max. \\
\hline \multicolumn{7}{|l|}{ Dependent variables } \\
\hline COLL & 1702 & 0.717 & 1 & 0.450 & 0 & 1 \\
\hline GUAR & 1702 & 0.667 & 1 & 0.471 & 0 & 1 \\
\hline \multicolumn{7}{|l|}{ Riskiness of borrower } \\
\hline $\begin{array}{c}\text { SCORE } \\
\text { Monitoring }\end{array}$ & \multicolumn{5}{|c|}{ Monitoring by lender } & 78 \\
\hline DOC_FREQ & 1702 & 3.032 & 3 & 1.080 & 1 & 4 \\
\hline \multicolumn{7}{|l|}{ Relationship between borrower and lender } \\
\hline LOGDURATION & 1702 & 3.301 & 3.497 & 0.722 & 0 & 4.595 \\
\hline SCOPE & 1702 & 4.208 & 4 & 1.767 & 0 & 9 \\
\hline BANKS & 1702 & 4.117 & 4 & 2.834 & 0 & 30 \\
\hline ONE_BANK & 1702 & 0.111 & 0 & 0.314 & 0 & 1 \\
\hline \multicolumn{7}{|l|}{ Terms of loan contracts } \\
\hline RATE & 1702 & 1.668 & 1.625 & 0.697 & 0 & 6 \\
\hline \multicolumn{7}{|l|}{ Borrower characteristics } \\
\hline LOGSALES & 1702 & 14.753 & 14.852 & 1.288 & 9.930 & 18.310 \\
\hline CASH_RATIO & 1702 & 0.168 & 0.103 & 0.293 & 0 & 7.475 \\
\hline MATURITY & 1702 & 0.585 & 0.606 & 0.323 & 0 & 1 \\
\hline IND1(Construction) & 1702 & 0.290 & 0 & 0.454 & 0 & 1 \\
\hline IND2(Manufacturing) & 1702 & 0.148 & 0 & 0.355 & 0 & 1 \\
\hline IND3(IT and Transportation, & 1702 & 0.039 & 0 & 0.195 & 0 & 1 \\
\hline IND4(Wholesale) & 1702 & 0.179 & 0 & 0.384 & 0 & 1 \\
\hline IND5(Retail) & 1702 & 0.115 & 0 & 0.319 & 0 & 1 \\
\hline IND6(Realestate) & 1702 & 0.038 & 0 & 0.192 & 0 & 1 \\
\hline IND7(Restaurants) & 1702 & 0.004 & 0 & 0.059 & 0 & 1 \\
\hline IND8(Services) & 1702 & 0.108 & 0 & 0.310 & 0 & 1 \\
\hline IND9(Other) & 1702 & 0.079 & 0 & 0.269 & 0 & 1 \\
\hline \multicolumn{7}{|l|}{ Lender characteristics } \\
\hline SME_LOANS & 1702 & 0.485 & 0.464 & 0.113 & 0.228 & 0.806 \\
\hline BANK_SHARE & 1702 & 0.034 & 0.006 & 0.043 & 0.000 & 0.109 \\
\hline NPL & 1702 & 0.085 & 0.086 & 0.029 & 0.026 & 0.221 \\
\hline \multicolumn{7}{|l|}{ Instrumental variables } \\
\hline FIRMAGE & 1702 & 47.154 & 43 & 27.943 & 1 & 434 \\
\hline $\mathrm{HHI}$ & 1702 & 2304.538 & 2237.182 & 1396.269 & 402.239 & 6135.069 \\
\hline CITY_SHARE & 1702 & 0.248 & 0.104 & 0.235 & 0.011 & 0.597 \\
\hline$O W N E R \_R E P$ & 1702 & 0.578 & 1 & 0.494 & 0 & 1 \\
\hline OWNER_FAMILY & 1702 & 1.374 & 1 & 1.381 & 0 & 8 \\
\hline LAND RATIO & 1702 & 0.135 & 0.106 & 0.128 & 0 & 0.842 \\
\hline
\end{tabular}


Table 3. Probit Estimation for COLL and Exogeneity Test for GUAR and RATE

\begin{tabular}{|c|c|c|c|}
\hline \multicolumn{4}{|c|}{$\begin{array}{l}\text { Probit regression } \\
\text { Dependent variable: } C O L L\end{array}$} \\
\hline & Coeff. & $\bar{z}$ & p-value \\
\hline$\overline{G U A R}$ & 0.68 & 8.18 & 0.000 \\
\hline SCORE & 0.00 & -0.31 & 0.753 \\
\hline DOC_FREQ & -0.13 & -3.30 & 0.001 \\
\hline LOGDURATION & 0.43 & 8.06 & 0.000 \\
\hline SCOPE & 0.09 & 3.65 & 0.000 \\
\hline BANKS & 0.01 & 0.72 & 0.470 \\
\hline ONE_BANK & -0.01 & -0.05 & 0.957 \\
\hline RATE & 0.32 & 4.82 & 0.000 \\
\hline LOGSALES & 0.08 & 2.01 & 0.044 \\
\hline CASH_RATIO & 0.26 & 1.45 & 0.146 \\
\hline MATURITY & -0.61 & -4.98 & 0.000 \\
\hline IND1 & 0.40 & 2.68 & 0.007 \\
\hline IND2 & 0.13 & 0.81 & 0.420 \\
\hline IND3 & 0.29 & 1.23 & 0.220 \\
\hline IND4 & 0.15 & 0.92 & 0.357 \\
\hline IND5 & 0.40 & 2.22 & 0.026 \\
\hline IND6 & 0.89 & 3.24 & 0.001 \\
\hline IND7 & -0.18 & -0.32 & 0.746 \\
\hline IND8 & -0.11 & -0.68 & 0.498 \\
\hline SME_LOANS & -0.60 & -1.33 & 0.183 \\
\hline BANK_SHARE & -2.01 & -1.69 & 0.091 \\
\hline$N P L$ & 0.76 & 0.58 & 0.565 \\
\hline LAND_RATIO & 3.70 & 9.96 & 0.000 \\
\hline Constant & -2.87 & -3.82 & 0.000 \\
\hline Obs. & 1702 & & \\
\hline Log likelihood & -749.96 & & \\
\hline LR chi squared (23) & 526.82 & & \\
\hline Prob > chi squared & 0 & & \\
\hline Pseud R squared & 0.2599 & & \\
\hline \multicolumn{4}{|c|}{ 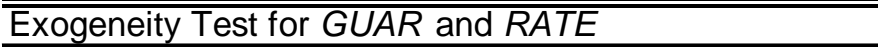 } \\
\hline & Coeff. & $\mathrm{Z}$ & p-value \\
\hline resid_GUAR & -1.71 & -5.90 & 0.000 \\
\hline resid RATE & 0.05 & 0.06 & 0.955 \\
\hline
\end{tabular}


Table 4. Validity of Instruments for GUAR

\begin{tabular}{|c|c|c|c|c|c|c|}
\hline \multicolumn{7}{|c|}{$\begin{array}{l}\text { Probit regression } \\
\text { Dependent variable: GUAR }\end{array}$} \\
\hline & Coeff. & Z & p-value & Coeff. & Z & p-value \\
\hline \multicolumn{4}{|l|}{$\overline{\text { SCORE }}$} & 0.00 & 0.00 & 0.998 \\
\hline \multicolumn{4}{|l|}{ DOC_FREQ } & -0.10 & -2.85 & 0.004 \\
\hline \multicolumn{4}{|l|}{ LOGDURATION } & 0.12 & 2.40 & 0.016 \\
\hline \multicolumn{4}{|l|}{ SCOPE } & 0.04 & 1.89 & 0.059 \\
\hline \multicolumn{4}{|l|}{ BANKS } & -0.01 & -0.99 & 0.321 \\
\hline \multicolumn{4}{|l|}{ ONE_BANK } & -0.17 & -1.31 & 0.191 \\
\hline \multicolumn{4}{|l|}{ LOGSALES } & -0.23 & -5.88 & 0.000 \\
\hline \multicolumn{4}{|l|}{ CASH_RATIO } & -0.01 & -0.07 & 0.945 \\
\hline \multicolumn{4}{|l|}{ MATURITY } & -0.43 & -3.65 & 0.000 \\
\hline \multicolumn{4}{|l|}{ IND1 } & 0.12 & 0.85 & 0.394 \\
\hline \multicolumn{4}{|l|}{ IND2 } & 0.13 & 0.80 & 0.422 \\
\hline \multicolumn{4}{|l|}{ IND3 } & 0.25 & 1.22 & 0.222 \\
\hline \multicolumn{4}{|l|}{ IND4 } & 0.45 & 2.95 & 0.003 \\
\hline \multicolumn{4}{|l|}{ IND5 } & 0.51 & 3.04 & 0.002 \\
\hline \multicolumn{4}{|l|}{ IND6 } & -0.07 & -0.32 & 0.752 \\
\hline \multicolumn{4}{|l|}{ IND7 } & -0.13 & -0.22 & 0.826 \\
\hline \multicolumn{4}{|l|}{ IND8 } & 0.04 & 0.27 & 0.786 \\
\hline \multicolumn{4}{|l|}{ SME_LOANS } & 1.08 & 2.52 & 0.012 \\
\hline \multicolumn{4}{|l|}{ BANK_SHARE } & -2.30 & -2.10 & 0.036 \\
\hline \multicolumn{4}{|l|}{$N P L$} & -2.47 & -2.00 & 0.045 \\
\hline OWNER_REP & 0.86 & 9.11 & 0.000 & 0.77 & 7.65 & 0.000 \\
\hline OWNER_FAMILY & 0.15 & 4.06 & 0.000 & 0.08 & 2.08 & 0.037 \\
\hline Constant & -0.20 & -4.12 & 0.000 & 2.93 & 4.70 & 0.000 \\
\hline Obs. & 1702 & & & 1702 & & \\
\hline Log likelihood & -924.01 & & & -841.291 & & \\
\hline LR chi squared (23) & 318.21 & & & 483.65 & & \\
\hline Prob > chi squared & 0 & & & 0 & & \\
\hline Pseud R squared & 0.1469 & & & 0.2233 & & \\
\hline Chi squared value th & instruments & jointly & ero & 151.00 & & \\
\hline $\mathrm{p}$-value & & & & 0.0000 & & \\
\hline
\end{tabular}


Table 5. Simultaneous System Probit Estimation for COLL

\begin{tabular}{|c|c|c|c|}
\hline \multicolumn{4}{|c|}{$\begin{array}{l}\text { Instrumental variable probit regression } \\
\text { Dependent variable: } C O L L ; \text { Instrumented variable: GUAF } \\
\text { Instrumental variables: } O W N E R \_R E P, O W N E R \_F A M I L Y\end{array}$} \\
\hline & Coeff. & $\bar{z}$ & $\overline{p \text {-value }}$ \\
\hline GUAR & 1.50 & 9.73 & 0.000 \\
\hline SCORE & -0.01 & -0.78 & 0.435 \\
\hline DOC_FREQ & -0.10 & -2.59 & 0.010 \\
\hline LOGDURATION & 0.37 & 6.82 & 0.000 \\
\hline SCOPE & 0.06 & 2.62 & 0.009 \\
\hline BANKS & 0.01 & 0.91 & 0.365 \\
\hline ONE_BANK & 0.05 & 0.44 & 0.662 \\
\hline RATE & 0.28 & 4.47 & 0.000 \\
\hline LOGSALES & 0.17 & 4.02 & 0.000 \\
\hline CASH_RATIO & 0.22 & 1.35 & 0.177 \\
\hline MATURITY & -0.42 & -3.43 & 0.001 \\
\hline IND1 & 0.27 & 1.82 & 0.068 \\
\hline IND2 & -0.01 & -0.04 & 0.971 \\
\hline IND3 & 0.19 & 0.83 & 0.407 \\
\hline IND4 & -0.08 & -0.49 & 0.625 \\
\hline IND5 & 0.17 & 0.94 & 0.345 \\
\hline IND6 & 0.81 & 3.05 & 0.002 \\
\hline IND7 & -0.11 & -0.21 & 0.835 \\
\hline IND8 & -0.12 & -0.75 & 0.452 \\
\hline SME_LOANS & -0.87 & -2.00 & 0.046 \\
\hline BANK_SHARE & -1.31 & -1.14 & 0.254 \\
\hline$N P L$ & 1.53 & 1.20 & 0.231 \\
\hline LAND_RATIO & 3.32 & 9.23 & 0.000 \\
\hline Constant & -4.16 & -5.62 & 0.000 \\
\hline Obs. & 1702 & & \\
\hline Log likelihood & -1581.02 & & \\
\hline Wald chi squared (45) & 1048.82 & & \\
\hline Prob>chi squared & 0.0000 & & \\
\hline
\end{tabular}


Table 6. Probit Estimation for GUAR and

Exogeneity Test for COLL and RATE

\begin{tabular}{|c|c|c|c|}
\hline \multicolumn{4}{|c|}{$\begin{array}{l}\text { Probit regression } \\
\text { Dependent variable: GUAR }\end{array}$} \\
\hline \multicolumn{2}{|r|}{ Coeff. } & $z$ & p-value \\
\hline$\overline{C O L L}$ & 0.56 & 6.63 & 0.000 \\
\hline SCORE & 0.01 & 1.00 & 0.316 \\
\hline DOC_FREQ & -0.06 & -1.49 & 0.135 \\
\hline LOGDURATION & 0.04 & 0.83 & 0.407 \\
\hline SCOPE & 0.03 & 1.48 & 0.140 \\
\hline BANKS & -0.02 & -1.25 & 0.210 \\
\hline ONE_BANK & -0.19 & -1.48 & 0.139 \\
\hline RATE & 0.17 & 2.79 & 0.005 \\
\hline LOGSALES & -0.22 & -5.51 & 0.000 \\
\hline CASH_RATIO & -0.03 & -0.21 & 0.837 \\
\hline MATURITY & -0.25 & -2.11 & 0.035 \\
\hline IND1 & 0.05 & 0.36 & 0.721 \\
\hline IND2 & 0.08 & 0.48 & 630 \\
\hline IND3 & 0.14 & 0.67 & 506 \\
\hline IND4 & 0.42 & 2.70 & 0.007 \\
\hline IND5 & 0.41 & 2.40 & 0.016 \\
\hline IND6 & -0.25 & -1.15 & 0.249 \\
\hline IND7 & -0.03 & -0.05 & 0.963 \\
\hline IND8 & 0.02 & 0.11 & 0.909 \\
\hline SME_LOANS & 1.11 & 2.56 & 0.011 \\
\hline BANK_SHARE & -1.83 & -1.64 & 0.100 \\
\hline$N P L$ & -2.91 & -2.32 & 0.020 \\
\hline OWNER_REP & 0.69 & 6.77 & 0.000 \\
\hline OWNER_FAMILY & 0.06 & 1.61 & 0.108 \\
\hline Constant & 2.03 & 2.84 & 0.004 \\
\hline$\overline{\text { Obs. }}$ & 1702 & & \\
\hline Log likelihood & -813.189 & & \\
\hline LR chi squared(23) & 539.85 & & \\
\hline Prob > chi squared & 0 & & \\
\hline Pseud R squared & 0.2492 & & \\
\hline \multicolumn{4}{|c|}{$\overline{\text { Exogeneity Test for COLL and RATE }}$} \\
\hline & Coeff. & $z$ & p-value \\
\hline resid_COLL & -0.16 & -0.44 & 0.661 \\
\hline resid_RATE & -0.21 & -0.26 & 0.798 \\
\hline
\end{tabular}


Table 7(a). Simultaneous System Probit Estimation for COLL by Firm Size

\begin{tabular}{|c|c|c|c|c|c|c|}
\hline \multicolumn{7}{|c|}{$\begin{array}{l}\text { Dependent variable: COLL; Instrumented variable: GUAR; } \\
\text { Instrumental variables: OWNER REP, OWNER FAMILY }\end{array}$} \\
\hline & Small firm & th $E M F$ & $<=62$ & Large firms & ith $E M P$ & $>62$ \\
\hline & Coeff. & z & $\mathrm{p}$-value & Coeff. & $z$ & $\mathrm{p}$-value \\
\hline$\overline{G U A R}$ & 1.62 & 7.06 & 0.000 & 1.36 & 5.80 & 0.000 \\
\hline SCORE & 0.00 & -0.41 & 0.680 & -0.01 & -0.90 & 0.366 \\
\hline$D O C \_F R E Q$ & -0.13 & -2.31 & 0.021 & -0.11 & -1.80 & 0.072 \\
\hline LOGDURATION & 0.34 & 4.91 & 0.000 & 0.37 & 4.12 & 0.000 \\
\hline SCOPE & 0.07 & 1.98 & 0.047 & 0.07 & 1.99 & 0.046 \\
\hline BANKS & 0.02 & 0.73 & 0.468 & 0.01 & 0.45 & 0.650 \\
\hline ONE BANK & 0.01 & 0.03 & 0.973 & 0.13 & 0.57 & 0.567 \\
\hline RATE & 0.29 & 3.66 & 0.000 & 0.30 & 2.70 & 0.007 \\
\hline LOGSALES & 0.01 & 0.09 & 0.931 & 0.17 & 2.00 & 0.045 \\
\hline CASH_RATIO & 0.12 & 0.57 & 0.570 & 0.31 & 1.32 & 0.188 \\
\hline MATURITY & -0.39 & -2.57 & 0.010 & -0.59 & -2.58 & 0.010 \\
\hline IND1 & 0.10 & 0.46 & 0.643 & 0.24 & 1.12 & 0.263 \\
\hline IND2 & -0.01 & -0.06 & 0.949 & -0.07 & -0.26 & 0.797 \\
\hline IND3 & -0.07 & -0.17 & 0.862 & 0.10 & 0.32 & 0.746 \\
\hline IND4 & 0.10 & 0.46 & 0.643 & -0.24 & -0.96 & 0.338 \\
\hline IND5 & 0.20 & 0.82 & 0.411 & 0.08 & 0.29 & 0.770 \\
\hline IND6 & 0.81 & 2.63 & 0.009 & 6.80 & 0.00 & 1.000 \\
\hline IND7 & -5.49 & 0.00 & 1.000 & -0.41 & -0.69 & 0.490 \\
\hline IND8 & -0.02 & -0.10 & 0.920 & -0.29 & -1.16 & 0.248 \\
\hline SME_LOA & 0.01 & 0.03 & 0.980 & -1.74 & -2.47 & 0.014 \\
\hline BANK_SHARE & 0.50 & 0.29 & 0.771 & -3.32 & -2.05 & 0.040 \\
\hline$N P L$ & -1.20 & -0.67 & 0.502 & 3.45 & 1.76 & 0.078 \\
\hline LAND_RATIO & 3.33 & 7.09 & 0.000 & 3.31 & 5.45 & 0.000 \\
\hline Constänt & -2.31 & -2.17 & 0.030 & -3.25 & -2.21 & 0.027 \\
\hline Obs. & 858 & & & 844 & & \\
\hline Log likelihood & -782.766 & & & -743.72 & & \\
\hline Wald chi squared & 499.92 & & & 537.7 & & \\
\hline Prob $>$ chi squared & 0 & & & 0 & & \\
\hline
\end{tabular}

Note: EMP stands for the number of employees.
Table 7(b). Probit Estimation for GUAR by Firm Size

\section{Probit regression}

Dependent variable: GUAR

\begin{tabular}{|c|c|c|c|c|c|c|}
\hline & \multicolumn{3}{|c|}{ Small firms with $E M P<=62$} & \multicolumn{3}{|c|}{ Large firms with $E M P>62$} \\
\hline & Coeff. & $z$ & p-value & Coeff. & z & p-value \\
\hline$\overline{C O L L}$ & 0.72 & 6.19 & 0.000 & 0.43 & 3.27 & 0.001 \\
\hline SCORE & 0.01 & 1.14 & 0.255 & 0.01 & 0.68 & 0.498 \\
\hline$D O C \_F R E Q$ & -0.01 & -0.14 & 0.891 & -0.07 & -1.43 & 0.154 \\
\hline LOGDURATION & 0.07 & 0.98 & 0.327 & 0.08 & 0.88 & 0.380 \\
\hline SCOPE & -0.02 & -0.70 & 0.483 & 0.08 & 2.60 & 0.009 \\
\hline BANKS & -0.03 & -1.41 & 0.158 & 0.00 & 0.20 & 0.840 \\
\hline ONE_BANK & -0.16 & -1.00 & 0.318 & -0.25 & -1.13 & 0.258 \\
\hline RATE & 0.05 & 0.63 & 0.531 & 0.37 & 3.53 & 0.000 \\
\hline LOGSALES & -0.10 & -1.57 & 0.117 & -0.37 & -4.69 & 0.000 \\
\hline CASH_RATIO & 0.05 & 0.26 & 0.797 & -0.21 & -0.76 & 0.449 \\
\hline MATURITY & 0.06 & 0.36 & 0.717 & -0.78 & -4.06 & 0.000 \\
\hline IND1 & -0.02 & -0.10 & 0.918 & 0.09 & 0.46 & 0.644 \\
\hline IND2 & -0.10 & -0.45 & 0.652 & 0.40 & 1.60 & 0.111 \\
\hline IND3 & 0.44 & 1.13 & 0.260 & 0.08 & 0.28 & 0.783 \\
\hline IND4 & 0.19 & 0.83 & 0.408 & 0.63 & 2.63 & 0.009 \\
\hline IND5 & 0.14 & 0.55 & 0.581 & 0.73 & 2.86 & 0.004 \\
\hline IND6 & -0.24 & -0.91 & 0.364 & -0.91 & -1.62 & 0.105 \\
\hline IND7 & & & & 0.55 & 0.86 & 0.392 \\
\hline IND8 & -0.17 & -0.72 & 0.471 & 0.15 & 0.62 & 0.537 \\
\hline SME_LOANS & 0.22 & 0.35 & 0.725 & 2.25 & 3.43 & 0.001 \\
\hline BANK_SHARE & -2.65 & -1.49 & 0.136 & -1.38 & -0.91 & 0.361 \\
\hline$N P L$ & 0.50 & 0.26 & 0.794 & -4.75 & -2.65 & 0.008 \\
\hline OWNER_REP & 0.97 & 6.04 & 0.000 & 0.44 & 3.13 & 0.002 \\
\hline OWNER_FAMIL & -0.01 & -0.20 & 0.841 & 0.13 & 2.23 & 0.026 \\
\hline Constant & 0.31 & 0.29 & 0.771 & 3.63 & 2.67 & 0.008 \\
\hline Obs. & 857 & & & 844 & & \\
\hline Log likelihood & -365.231 & & & -409.537 & & \\
\hline LR chi square( $2 i$ & 228.4 & & & 328.95 & & \\
\hline Prob > chi squar & 0 & & & 0 & & \\
\hline Pseud R square & 0.2382 & & & 0.2865 & & \\
\hline
\end{tabular}

Note: EMP stands for the number of employees. 
Table 8(a). Simultaneous System Probit Estimation for COLL for Sample Including Firms With Government Guarantees for Part of Their Loans nstrumental variable probit regression

Dependent variable: COLL ; Instrumented variable: GUAR; Instrumental variables: OWNER_REP, OWNER_FAMILY

\begin{tabular}{|c|c|c|c|}
\hline & Coeff. & $z$ & $p$-value \\
\hline$\overline{G U A R}$ & 1.35 & 9.28 & 0.000 \\
\hline SCORE & -0.01 & -1.55 & 0.121 \\
\hline$D O C \_F R E Q$ & -0.14 & -5.02 & 0.000 \\
\hline LOGDURATION & 0.38 & 10.07 & 0.000 \\
\hline SCOPE & 0.07 & 3.69 & 0.000 \\
\hline BANKS & 0.00 & 0.06 & 0.954 \\
\hline ONE_BANK & -0.01 & -0.09 & 0.928 \\
\hline RATE & 0.17 & 4.26 & 0.000 \\
\hline GOVGUAR & 0.30 & 4.02 & 0.000 \\
\hline LOGSALES & 0.15 & 4.69 & 0.000 \\
\hline CASH_RATIO & 0.45 & 2.94 & 0.003 \\
\hline MATURITY & -0.40 & -4.20 & 0.000 \\
\hline IND1 & 0.34 & 2.87 & 0.004 \\
\hline IND2 & 0.08 & 0.66 & 0.511 \\
\hline IND3 & 0.05 & 0.30 & 0.766 \\
\hline IND4 & 0.01 & 0.10 & 0.920 \\
\hline IND5 & 0.19 & 1.35 & 0.176 \\
\hline IND6 & 1.00 & 4.15 & 0.000 \\
\hline IND7 & -0.39 & -1.16 & 0.248 \\
\hline IND8 & -0.18 & -1.41 & 0.159 \\
\hline SME_LOANS & -0.58 & -1.81 & 0.070 \\
\hline BANK_SHARE & -1.56 & -1.73 & 0.083 \\
\hline$N P L$ & 0.50 & 0.53 & 0.599 \\
\hline LAND_RATIO & 3.27 & 12.32 & 0.000 \\
\hline Constant & -3.46 & -6.11 & 0.000 \\
\hline Obs. & 3934 & & \\
\hline Log likelihood & -2525.28 & & \\
\hline Wald chi squared (47) & 1834.42 & & \\
\hline Prob $>$ chi squared & 0.0000 & & \\
\hline
\end{tabular}

Table 8(b). Probit Estimation for GUAR for Sample Including Firms With Government Guarantees for Part of Their Loans

Probit regression

Dependent variable: GUAR

\begin{tabular}{lrrr}
\hline & Coeff. & \multicolumn{2}{l}{ z } \\
\hline COLL & 0.55 & 7.69 & 0.000 \\
SCORE & 0.01 & 1.62 & 0.105 \\
DOC_FREQ & -0.07 & -2.46 & 0.014 \\
LOGDURATION & 0.03 & 0.64 & 0.524 \\
SCOPE & 0.05 & 2.56 & 0.010 \\
BANKS & -0.03 & -2.27 & 0.023 \\
ONE_BANK & -0.20 & -1.91 & 0.056 \\
RATE & 0.13 & 2.91 & 0.004 \\
GOVGUAR & 0.77 & 10.53 & 0.000 \\
LOGSALES & -0.17 & -5.22 & 0.000 \\
CASH_RATIO & -0.04 & -0.29 & 0.774 \\
MATURITY & -0.29 & -2.94 & 0.003 \\
IND1 & 0.04 & 0.30 & 0.762 \\
IND2 & 0.08 & 0.60 & 0.548 \\
IND3 & 0.19 & 1.05 & 0.294 \\
IND4 & 0.38 & 2.90 & 0.004 \\
IND5 & 0.49 & 3.28 & 0.001 \\
IND6 & -0.03 & -0.14 & 0.888 \\
IND7 & 0.24 & 0.55 & 0.580 \\
IND8 & 0.02 & 0.16 & 0.876 \\
SME_LOANS & 1.33 & 3.90 & 0.000 \\
BANK_SHARE & -1.04 & -1.15 & 0.252 \\
NPL & -2.65 & -2.62 & 0.009 \\
OWNER_REP & 0.53 & 6.54 & 0.000 \\
OWNER_FAMILY & 0.07 & 2.35 & 0.019 \\
Constant & 1.24 & 2.13 & 0.033 \\
\hline ObS. & 3934 & & \\
LOg likelihood & -1184.68 & & \\
LR chi squared(25) & 1189.56 & & \\
Prob > chi squared & 0 & & \\
Pseud R squared & 0.3342 & & \\
\hline & & & \\
\hline
\end{tabular}

